\title{
Isolasi dan Karakterisasi Actinomycetes Sebagai Penghasil Antibiotik Dari Sampel Tanah Pada Peternakan Sapi di Kecamatan Galesong Kabupaten Takalar
}

\author{
ADRIANI $^{1}$, YESSICA FEBRIWANTI TULAK ${ }^{1}$ \\ ${ }^{1}$ Jurusan Pendidikan Biologi, Fakultas Matematika dan Ilmu Pengetahuan Alam, STKIP-PI \\ J1. A.P. Pettarani No. 99 B Makassar 90125 \\ email: adrimarsya@gmail.com
}

\begin{abstract}
A research on the isolation and characteristics of the antibiotic-producing actinomycetes from soil sample on dairy farms in the district Galesong Takalar has been done for obtaining antibioticproducing actinomycetes isolates. This study is an exploratory study with laboratory. This research method is the agar diffusion method. Isolation was conducted using scratch method, $7 \times 24$ hour incubation period. Isolates obtained was purified on a medium Glycerol Yeast Extract Agar (GYEA). Isolates fermented for $7 \times 24$ hours on the tube with the intensity of $170 \mathrm{rpm}$ at room temperature. Fermentation result was tested for antibiotic activity. Both isolates were effective as an antibiotic against bacteria used in the test.
\end{abstract}

Keywords: Actinomycetes, antibiotics, characterization, isolation, soil, Takalar

\section{PENDAHULUAN}

Banyaknya penyakit infeksi baru bermunculan yang menginfeksi manusia dan adanya resistensi terhadap antibiotic saat ini mendorong dilakukannya eksplorasi terhadap sumber-sumber antibiotic. Sumber mikroorganisme penghasil antibiotik antara lain berasal dari tanah, air laut, lumpur, kompos, isi rumen, limbah domestik, bahan makanan busuk dan lain-lain. Namun kebanyakan mikroba penghasil antibiotika diperoleh dari mikroba tanah. Banyak jasad renik yang diisolasi dari tanah ditemukan memiliki kemampuan menghasilkan zat-zat antibiotik. Mikroorganisme penghasil antibiotik meliputi golongan Bakteri, Actinomycetes, Fungi dan beberapa mikroba lainnya, kira-kira 70\% antibiotik dihasilkan oleh Actinomycetes jenis Streptomyces (Suwandi dalam Ambarwati, 2009), 20\% Fungi dan 10\% oleh Bakteri (Anonim, 2013). Selain sebagai antibakteri Actinomycetes juga berperan sebagai antijamur (Ariningsih, 2009; Sari, 2011).

Actinomycetes adalah mikroorganisme tanah dari kelas Schizomycetes yang bersifat saprofit, dekomposer serta mampu mendegradasi selulosa. Kisaran $\mathrm{pH}$ yang sesuai antara 6,5-8,0. Temperatur yang cocok untuk pertumbuhan Actinomycetes adalah 25$30^{\circ} \mathrm{C}$ namun pada suhu $55-65^{\circ} \mathrm{C}$ masih dapat tumbuh dalam jumlah cukup besar, khususnya genus Thermoactinomyces dan Streptomyces (Rao, 1994). Penelitian yang dilakukan oleh Jamaluddin (1993) dan Hasnawati (2001) telah berhasil mengisolasi dan mengidentifikasi mikroba tanah penghasil antimikroba pada beberapa tempat di Sulawesi Selatan. Actinomycetes yang berasal dari tanah sawah bersifat sebagai antibakteri terhadap Staphylococcus aureus tetapi tidak untuk Escherichia coli. Namun Actinomycetes yang berasal dari rizosper putri malu mampu menghambat pertumbuhan E.coli (Ambarwati, 2007 \& 2009). Dari hasil penelitian ini dapat diketahui bahwa perbedaan lokasi dapat mempengaruhi jenis mikroorganisme yang ada. Tujuan penelitian ini adalah untuk mengisolasi mikroba tanah dari kelas Actinomycetes dari tanah Peternakan Sapi di Kabupaten Takalar yang berpotensi sebagai antibiotika.

\section{METODE}

Pengambilan Sampel Tanah dilakukan menurut Rao (1994), selanjutnya dibuat suspensi dan dilakukan isolasi mikroba tanah menggunakan medium Glicerol Yeast Ekstrak 
Agar (GYEA). Koloni yang tumbuh selanjutnya dimurnikan pada medium GYEA sampai diperoleh biakan murni untuk selanjutnya disimpan sebagai stok. Pengamatan secara makroskopik dilakukan dengan melihat bentuk, warna dan permukaan koloni yang tumbuh pada medium sedangkan untuk pengamatan secara mikroskopik dilakukan melalui pengecatan gram.

Sebanyak satu ose biakan murni disuspensikan dengan $2 \mathrm{ml}$ larutan $\mathrm{NaCl}$ fisiologis kemudian diinokulasikan ke dalam $10 \mathrm{ml}$ medium Maltosa Yeast Broth (MYB), inkubasi selama 24 jam kemudian disentrifuse. Sebanyak $2 \mathrm{ml}$ inokulum dimasukkan ke dalam $10 \mathrm{ml}$ medium produksi, inkubasi pada suhu $30^{\circ} \mathrm{C}$ selama 120 jam kemudian disentrifuge dengan kecepatan 1000 rpm selama 15 menit. Paperdisk yang telah ditetesi dengan $0,2 \mathrm{ml}$ filtrate hasil sentrifuse selanjutnya diletakkan secara aseptis pada permukaan medium MHA yang telah berisi bakteri uji, inkubasi pada suhu $37^{\circ} \mathrm{C}$ selama 24 jam. Dilakukan pengamatan terhadap zona bening yang terbentuk.

\section{HASIL}

Dari hasil penelitian didapatkan 2 isolat bakteri dengan karakteristik yang menyerupai Actinomycetes dan dapat dilihat pada tabel 1 .

Tabel 1. Hasil pengamatan makroskopik dan mikroskopik dari sampel tanah peternakan sapi kec. Galesong Kab. Takalar

\begin{tabular}{lllll}
\hline No & \multicolumn{1}{c}{ Pengujian } & \multicolumn{1}{c}{ Isolat A } & \multicolumn{1}{c}{ Isolat B } \\
\hline 1 & Makroskopik & $\begin{array}{l}\text { Berbubuk, melekat erat pada } \\
\text { permukaan agar, koloni kecil } \\
\text { terpisah-pisah, berwarna putih }\end{array}$ & $\begin{array}{l}\text { Melekat erat pada permukaan } \\
\text { agar, koloni kecil terpisah- } \\
\text { pisah, berwarna putih }\end{array}$ \\
\hline 2 & Mikroskopik & $\begin{array}{l}\text { Bentuk basil, gram positif, bentuk } \\
\text { filament bercabang }\end{array}$ & $\begin{array}{l}\text { Bentuk basil, gram positif, } \\
\text { bentuk filament }\end{array}$ \\
\hline
\end{tabular}

Tabel 2. Daya hambat rata-rata $(\mathrm{mm})$ filtrat hasil Fermentasi terhadap mikroba uji

\section{Isolat}

Bakteri Uji Lama Fermentasi (Jam) Z Z Z Z Hambatan (mm)

\begin{tabular}{lccc} 
& & $\mathrm{A}$ & $\mathrm{B}$ \\
\hline E. coli & 120 & 10,7 & 10,4 \\
\hline Staphylococcus aureus & 120 & 11,9 & 10,9 \\
\hline
\end{tabular}

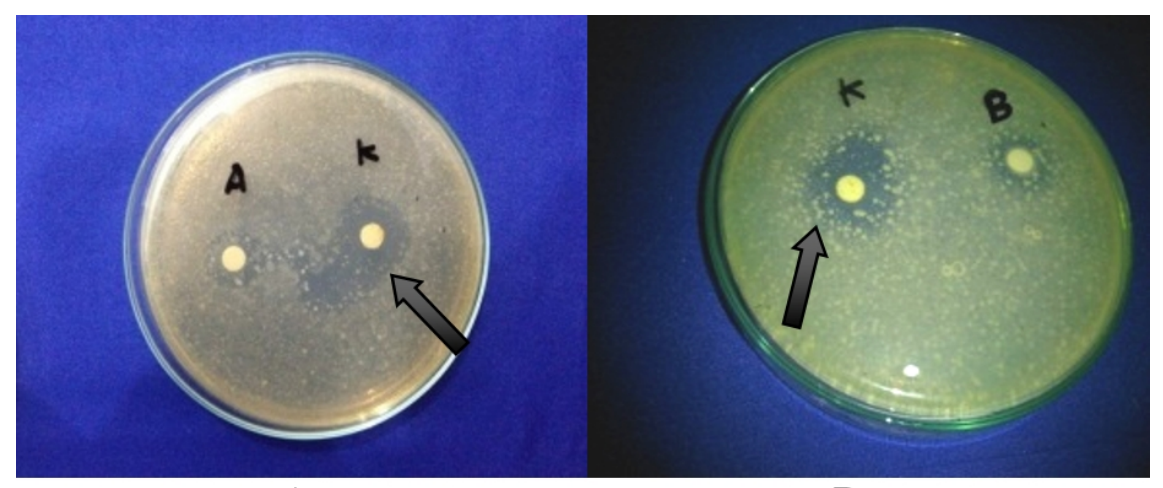

A

B

Gambar 1: Zona hambat yang terbentuk (A: Zona Hambat isolat A, B: Zona Hambat isolat B) 


\section{PEMBAHASAN}

Pada penelitian ini menggunakan medium spesifik yaitu medium GYEA. Medium ini mengandung gliserol dan K2HPO4 yang mampu mendukung pertumbuhan Actinomycetes dengan baik.

Dari hasil penelitian diperoleh 2 isolat Actinomycetes dan diperkirakan berasal dari genus Streptomyces. Hasil pengamatan secara mikroskopik menunjukkan bahwa isolat yang diisolasi tergolong bakteri gram positif (berwarna biru) dengan miselium yang panjang. Pengamatan secara makroskopik pada permukaan medium GYEA memperlihatkan ciri berbubuk, permukaan rata, melekat erat pada permukaan medium dan berwarna putih. Warna koloni awalnya putih dan lama kelamaan akan berubah menjadi hitam, hal ini terjadi akibat pigmentasi, sehingga timbul warna koloni yang berbeda sesuai jenis Actinomycetes yang diperoleh (Lechevalier dalam Kanti, 2005). Ciri khas dari genus Streptomyces sp adalah koloninya diselimuti oleh miselium udara yang bebas dan hifa yang dikelilingi oleh lapisan hidrofobik, hifa akan berubah menjadi warna tertentu apabila terjadi pembentukan spora (Susilowati et al, 2007).

Isolat A mampu menghambat pertumbuhan bakteri Escherichia coli dan Staphylococcus aureus dengan diameter hambatan masing-masing 10,7 $\mathrm{mm}$ dan 11,9 $\mathrm{mm}$. Isolat $\mathrm{B}$ mampu menghambat pertumbuhan bakteri Escherichia coli dan Staphylococcus aureus dengan diameter hambatan masing-masing 10,4 $\mathrm{mm}$ dan 10,9 $\mathrm{mm}$. Aktivitas penghambatan yang dimiliki oleh isolat A dan B tergolong sedang terhadap bakteri uji yang digunakan (Lee dan Hwang, 2002). Hal ini membuktikan bahwa kedua isolat berpotensi dijadikan sebagai antibiotik.

Actinomycetes khususnya Streptomyces merupakan mikroba endofit yang menjanjikan sebagai antibiotik. Beberapa penelitian menunjukkan bahwa Actinomycetes potensial dalam menghambat pertumbuhan bakteri salah satunya adalah Susilowati et al (2007) yang berhasil mengisolasi Actinomycetes dari lahan pertanian di Indonesia yang bersifat antibakteri terhadap E.coli dan Pseudomonas pseudomallei. Lokasi pengambilan sampel juga mempengaruhi jenis Actinomycetes yang diperoleh. Isolat Actinomycetes yang diperoleh dari tanah peternakan sapi di Kabupaten Takalar bersifat antibakteri terhadap E.coli dan Staphylococcus aureus. Begitu pula dengan isolat Actinomycetes dari rizosfer putri malu dan rizosfer jagung (Ambarwati, 2007; 2010), namun Actinomycetes yang diperoleh dari tanah sawah ternyata tidak mampu menghambat pertumbuhan bakteri E.coli (Ambarwati, 2009). Hal ini menunjukkan bahwa jenis Actinomycetes tergantung pada tipe tanah, karakteristik fisik, kadar bahan organik dan $\mathrm{pH}$ lingkungan (Kanti, 2005).

\section{KESIMPULAN}

Dari hasil isolasi Actinomycetes pada tanah peternakan Sapi Kecamatan Galesong Kabupaten Takalar didapatkan 2 jenis isolat Actinomycetes yang bersifat antibakteri terhadap Escherichia coli dan Staphylococcus aureus dengan aktivitas penghambatan sedang. Disarankan untuk melakukan penelitian lebih lanjut untuk mengetahui genus dan spesies dari isolat $\mathrm{A}$ dan $\mathrm{B}$.

\section{DAFTAR PUSTAKA}

Rizki AI. 2009. Isolasi Streptomyces dari Rizosfer Familia Poaceae yang Berpotensi Menghasilkan Anti Jamur Terhadap Candida albicans. [Skripsi]. Surakarta: Universitas Negeri Surakarta.

Ambarwati. 2007. Kajian Actinomycetes yang Berpotensi Menghasilkan Antibiotika dari Rhizozper Putri Malu (Mimosa pudica) dan Kucing-kucingan (Acalipha indica L.) Jurnal Sains dan Teknologi. vol 8 (1):114.

Ambarwati dan Gama A. 2009. Isolasi Actinomycetes dari Tanah Sawah Sebagai Penghasil Antibiotik. Jurnal Penelitian Sains dan Teknologi. vol 10 (2):110-111. Ambarwati CJ, Soegihardjo dan Sembiring L. 2010. Isolasi dan Identifikasi Streptomycetes dari Rizosfer Jagung (Zea mays L) yang Berpotensi Sebagai Penghasil Antibiotik. Jurnal Biota. vol 15(1). ISSN 0853-8670. 
Hasnawati. 2001. Isolasi dan Identifikasi Mikroorganisme Tanah Penghasil Antibiotika Asal Kecamatan Suppa Kabupaten Pinrang. [Skripsi]. Makassar: Fakultas MIPA Universitas Hasanuddin.

Jamaludin. 1993. Isolasi dan Identifikasi Mikroba Tanah Sebagai Penghasil Antifungi di Beberapa Kabupaten Propinsi Sulawesi Selatan. [Skripsi]. Makassar: Fakultas MIPA Universitas Hasanuddin.

Kanti dan Atit. 2005. Actinomycetes selulolitik dari Tanah Hutan Taman Nasional Bukit Duabelas Jambi. Jurnal Biodiversitas. vol. 6 (2):85-89. ISSN 1412-033X.

Lay WB. 1994. Analisis Mikroba di Laboratorium. Jakarta: PT. Raja Grafindo Persada.
Rao NSS. 1994. Mikroorganisme Tanah dan Pertumbuhan Tanaman. Edisi II. Jakarta: Universitas Indonesia press.

Sari WD. 2011. Aktivitas Antijamur dan Fraksinasi Ekstrak Butanol dari Isolat Actinomycetes AT 00244 Terhadap Jamur Fitopatogen Tanaman Kopi (Coffea Sp.) Rosselinia bunodes dan Phellinus lamaoensis. Malang: Universitas Brawijaya.

Susilowati ND, Ratih DH dan Erny Y. 2007. Isolasi dan Karakterisasi Actinomycetes Penghasil Antibakteri Enteropatogen Escherichia coli K1,1. Pseudomonas pseudomallei 0205 dan Listeria monocytogenes 5407. Jurnal AgroBiogen. vol 3(1):15-23

Waluyo L. 2008. Teknik dan Metode Dasar Mikrobiologi. Malang: UMM. 